\title{
The Mortgage Right as Murābaḥah Financing Security
}

\author{
Reni Anggriani1 ${ }^{1}$, Galang Rizki², Wida Febriansyah ${ }^{3}$ \\ ${ }^{1}$ Faculty of Law, Universitas Muhammadiyah Yogyakarta, anggriani@umy.ac.id \\ 2 Faculty of Law, Universitas Muhammadiyah Yogyakarta, galangrizki04@gmail.com \\ 3 Faculty of Law, Universitas Muhammadiyah Yogyakarta, widafebriansyah@gmail.com
}

\begin{abstract}
Introduction to The Problem: In order to guarantee the legal certainty for the Islamic banking customer in murābaḥah financing is the requirement of mortgage right. The bank customer may use mortgage right as collateral in murābahah financing. Furthermore, the right can be implemented in the indebtedness, which is different from debt.
\end{abstract}

Purpose/Objective Study: This research aims to find out the contract (al-'aqd) that is used by the shariah bank to implement the mortgage rights in murābahah financing. Design/Methodology/Approach: This study is normative juridical research with emphasis beginning on a legal event and then looking for references to a norm system. Therefore, this legal research is conducted by examining primary and secondary legal materials, and non-legal materials relating to the application of Mortgage Rights in Financing, especially for murābahah financing. In this study, the approach was the statute approach by examining all laws and regulations relating to legal issues, and case approach by examining several cases that have a relationship with the legal issues to be discussed.

Findings: The result of this study is that the implementation of mortgage right in murābahah financing is the possibility of using another contract made by sharia banking with its customers; the contract of acknowledgment of debt. This basis is used as the justification of the implementation of mortgage rights in murābahah financing.

Paper Type: Research Article

Keywords: Mortgage Right; Murābaḥah; Shariah Banking

\section{Introduction}

The current development shows progress in economic activities; many financial institutions provide the easiness for the people in practicing commercial activities. Financial institutions offer easy access for customers to get money loans for business needs and personal goods needs with a system of paying installments along with the interest set. This practice is certainly not in line with the Islamic view because interest is usury, and usury is a prohibited act (Haryoso, 2017).

The banking sector plays a role as an intermediation institution between parties who have excess funds with those who need funds. Banks that have sound financial performance are required in order to carry out the intermediation function properly (Rachmawati, Karim, \& Manan, 2019). That is why many scholars state that banking in a country is one of the agents of development. 
The function of the bank as the agents of development is related to its primary function, i.e., namely as an institution that collects funds from the community in the form of deposits and redistributes it to the community in the form of credit or financing. This function is commonly known as an intermediary financial function (Anshori, 2008).

The banking sector in Indonesia consists of two types, namely conventional banks and shariah banks, at both commercial and rural banks. The conventional bank is an interest banking system which is regulated based on Law No 10 of 1988 amendment of Law No 7 of 1992 on banking. Meanwhile, based on Section 1 number 13 of Law No 10 of 1998 on banking mentioned that shariah principle in shariah banks is that the contract ('aqd) legally regulated by Islamic law to collect the funds or to finance business activities which in line with the shariah principles. It is also mentioned that the definition of shariah principle is the Islamic law principles in banking system based on a fatwa issued by the authorized institution (Law No 21 of 2008) (Abdullah, 2017).

At present, the Islamic economy is developing, especially in the banking sector. The application of the principle of openness and profit-sharing can provide justice for customers and stability for banks. For this reason, since 2007, the development of Islamic banks has increased (Sari \& Anshori, 2018). In general, Islamic banks aim to encourage and accelerate the economic progress of a society by conducting banking, financial, commercial, and investment activities under the rules of Shariah. This goal is distinguishing Islamic banks from conventional banks, whose primary purpose is the achievement of the highest profit (Profit Maximization) (Santoso \& Ningrum, 2017).

The activities carried out by Islamic banks in achieving their objectives include murābaḥah financing. Murābaḥah is a short-term investment mechanism (Saeed, 2004). According to the DSN-MUI Fatwa/IV/2000, the definition of murābahah is to sell an item by emphasizing its purchase price to the buyer, and the buyer pays it at a price more than the original price as profit (Sam, 2006). Also, muräbahah is a sale and purchase contract that is made to someone where the seller conveys the purchase price to the buyer and the profits taken following the agreement of both parties. Thus, Islamic Financial Institutions act as sellers and customers as buyers, Islamic Financial Institutions provide goods needed by customers and will be repaid by customers along with agreed margin by Shariah Financial Institutions and customers with a predetermined period.

Initially, murābahah financing was not used as the primary form of financing in the Islamic banking system. Murābahah financing tends to be a tool to replace the interest in conventional banks and as one of the processes of economic Islamization. However, murābahah financing is not an ideal instrument for realizing the real goals of Islamic economics (Agza \& Darwanto, 2017). Still, financing using the murābahah contract is 
a favorite choice for Islamic banks in Indonesia (Rohman, 2017). Murābaḥah only involves two parties, namely sellers and buyers. In Islamic banking, the application of murābahah involves three parties, namely customers as buyers, banks as sellers and suppliers of goods to banks at the customer's request.

Murābahah contracts are generally used in the sale and purchase of goods, investments or goods used for personal use, such as vehicles, houses, production machinery, medical equipment, and others. This contract is more suitable for consumer and investment financing (Sari \& Anshori, 2018).

In reality, murābahah is more applied to the concept of murābahah bil wakālah. This concept means the bank authorizes customers to run sell and purchase of goods for customers' needs by conducting a wakālah (representative) agreement, which in the end the customer only submits the purchase receipt of goods as proof that the murābahah signed the contract could run according to the procedure (Afrida, 2016).

Based on the Fatwa of the National Shariah Council (Dewan Syariah Nasional/DSN) of the Indonesian Ulema Council (Majelis Ulama Indonesia/MUI), the characteristics of murābahah financing are different from loans that occur in conventional banks, i.e., the selling price of credit to consumers in conventional banks using interest rates that depend on the market situation. Meanwhile, muräbahah financing, the margin or profit level of murābahah (if there has been a recurrence permit) is fixed-margin, so the selling price cannot change (Asiyah, 2014).

Thus, from the beginning of the agreement until the repayment period, Islamic Financial Institutions cannot change the contract. In Islamic banking, goods that are bought and sold are required in the form of clearly priced property, such as cars or motorbikes. Meanwhile, conventional banking credit contracts to consumers in the form of loans contracts do not necessarily have a transparent kind of goods (Asiyah, 2014). In implementing murābaḥah financing, there are several risks. This financing risk is a risk caused by the inability of the customer to return several loans given by Islamic banks, along with the compensation by a predetermined period (Afif \& Mawardi, 2014).

From many studies on Islamic banks, there is still no research that examines how a mortgage can be applied in murābahah financing. Interestingly, murābaḥah financing adheres to a capital-based shariah banking system (equity) rather than debt. Meanwhile, the mortgage is an additional agreement of a debt. The problem arises because practically when murābaḥah financing is above Rp. 50,000,000 (fifty million rupiahs), then the mortgage is required.

\section{Methodology}




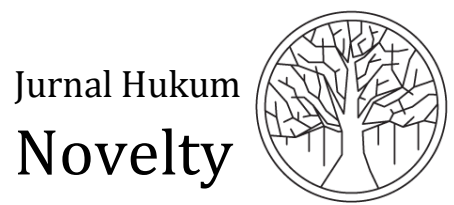

Volume 10, Issue 01, 2019, pp. 43-51

This study is normative juridical research with emphasis beginning on a legal event and then looking for references to a norm system. Therefore, this legal research is conducted by examining primary and secondary legal materials, and non-legal materials relating to the application of Mortgage Rights in Financing, especially for murābahah financing. In this study, the approach was the statute approach by examining all laws and regulations relating to legal issues, and case approach by examining several cases that have a relationship with the legal issues to be discussed.

In order to complete the legal material and complete the weakness in this study, the research informant was required. Research informant is those who are considered or qualified as parties who can clarify the legal issues under review. The research informant is the official certifier of title deeds notary services, shariah banking, and national land agency (Marzuki, 2005).

In this study, legal material collection techniques were carried out in two ways. First, collecting the data through interview. In conducting interviews, structured guidelines and semi-structured guidelines are used. In interviews, several questions that have been managed in a structured manner were delivered to the speakers. Therefore, some questions are deepened to get more information, then complete and in-depth answers can be obtained. Second, gathering the legal material by studying relevant literature and documents related to the research.

In this study, the legal material analysis technique carried out in a descriptive qualitative method. The analysis of research results is the main stage in the preparation of the research result both the results of research obtained by primary legal materials, as well as from secondary legal materials and non-legal materials. From three legal materials, a series of analyses carried out based on hypotheses obtained in the research process.

\section{Analysis and Results}

Shariah banks are banks that operate under Shariah principles, which means the procedures operate according to the provisions of the Quran and Hadith. The meaning of banks operating under Shariah principles is that banks operate based on Shariah provisions, especially those concerning the procedures for Islamic social interaction (mu'âmalah). In the process of mu'ämalah, the practices that are feared to contain elements of usury must be shunned and replaced with investment activities based on profit sharing and trade financing.

In operating a Shariah bank, one of the efforts to avoid deviations from Shariah provisions is to have the manager and the head of the bank who master the principle of mu'ämalah in Islam. Also, a Shariah Supervisory Board (Dewan Pengawas Syariah/DPS) has formed, which has the task to supervise the bank operations so that the shariah bank does not deviate from Islamic principles. 
Apart from being based on the Quran and Hadith, according to positive law in Indonesia, the basis for operating Islamic banks is Law Number 21 of 2008 on Islamic Banking. Government Regulation, No 72 of 1992 on banks based on profit sharing principles, regulates provisions regarding the process of establishing a Bank Umum Nirbunga (Non-interest Commercial Bank). Based on Article 28 and 29 the Decree of the Board of Managing Directors of Bank Indonesia No 32/34/KEP/DIR May 12, 1999, on banks based on profit sharing principles regulates several business activities that can be carried out by Islamic Banks.

The basis for the operation of Islamic Banking is Law No 50 of 2009 as the second amendment of Law No 7 of 1989 on Religious Courts. In the law of religious court procedure, there is an understanding of shariah economics and the existence of absolute competence of the Religious Courts in resolving shariah economic disputes. Other regulations specifically governing contract in business activities based on shariah principles are Bank Indonesia Regulation No 10/16/PBI/2008 on amendments to Bank Indonesia Regulation No 9/19/PBI/2007 on Implementation of Shariah Principles in Activities of Fundraising and Distribution Funds and Shariah Bank Services.

In general, the terms and conditions of the contract are regulated in article 22 of Kompilasi Hukum Ekonomi Syari'ah (The Compilation of Sharia Economic Law, abbreviated as KHES). KHES, which covers the subject of the contract (al-äqidain), the object of the contract (mahallul 'aqd), the aim of the contract (maudü'ul 'aqd), and the deal (al-ijāb and al-qabül/șigatul 'aqd). In the KHES Provisions, the skills of legal subjects are regulated in Article 23 paragraph (2): "the person who makes the contract must be competent in law, rational and tamyizz)" (Otoritas Jasa Keuangan, 2016). The definition of debt, according to the Indonesian Dictionary, is money borrowed from other people. Meanwhile, debtor accounts mean money that is lent to someone (can be billed from others) (Poerwadarminto, 2003). The definition of debt is the same as the loan agreement found in the provisions of the Civil Code Article 1754. It reads, "lending and borrowing is an agreement where one party gives the other party a certain amount of goods and is discharged due to usage, provided that the latter will return the same amount of the same type of situation (Subekti \& Tjitrosudibyo, 1992)."

In shariah terminology, fiqh scholars differed in defining the debt. According to Hanafiah School, debt is obtaining benefits without compensation. Mālikiyah School defined the debt same as Hanafiah School, only they added with 'within a certain time.' Different from these two schools, Syāfi'iyah School defined debt as the ability to take advantage of someone who frees them, what is possible to use and remains the substance of the goods so that they can be returned to the owner. On the other hand, Hanbali School stated that the debt is the permission to take benefit of a specific substance without any reward or something else. Ibnu Rif ah, he said that the debt is the permission for obtaining the advantage of a particular substance in a halal way 


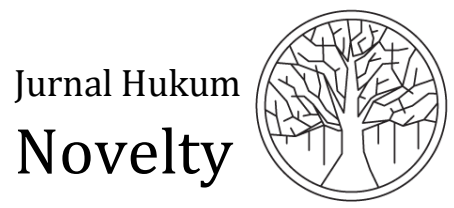

Volume 10, Issue 01, 2019, pp. 43-51

and so it will be returned in the same substance. Lastly, Al-Mawardi stated that debt is a way to provide benefit (Suhendi, 2014).

Article 1313 states that "an agreement is an act in which one or more people attach themselves to one or more other people." Agreement in the narrow sense is an agreement where two parties or more mutually tie themselves together to carry out a matter that is material in the field of wealth (Muhammad, 2010). Meanwhile, Subekti said that "An agreement is an event where someone promises to someone else or where two people promise each other to do certain things (Subekti, 2002)."

The definition of debt is the same as the loan agreement. It is regulated and determined in Chapter 13 of the Third Book of the Civil Code in Article 1754. It clearly states that "loan agreement is an agreement in which one party gives the other party a certain amount of goods which are depleted due to usage, with the provision of that the latter party will return the item with the same amount and condition (Supramono, 2013)." Based on that meaning, it can be known as the basic definition of debt and receivables. Debt is an obligation which is stated or cannot be stated in the amount of money both directly, or that will arise later, and the obligation arises because the existence of agreement or law that must be fulfilled by the debtor. If the debtor does not fulfill his obligation, it will give the creditor the right to get the debtor's assets. At the same time, receivables are creditors' claims to debtors for money, goods or services that are determined, and if the debtor is unable to fulfill, the creditor has the right to obtain fulfillment from the debtor's assets.

In the practices of shariah banking, the Deed of Mortgage Right is also used to guarantee the agreement on murābahah contract financing. The implementation of the deed is carried out under the Mortgage Rights Act as it also applied for granting credit guarantees to conventional banks.

The regulation which regulates the mortgage rights that currently applies and governs the guarantee of land rights is Law No 4 of 1996 on a mortgage right over land, and land-related objects, which can also be referred to as the Mortgage Rights Act of 1996, from now on referred to as UUHT (Undang-Undang Hak Tanggungan). The mortgage rights are collateral rights imposed on land rights, along with or no other objects which constitute a single entity with the land, for repayment of certain debts, which give a position that is prioritized to certain creditors to other creditors. The granting of the mortgage right is done by making the Deed of Mortgage Right by the notary following the applicable laws and regulations. The applicable UUHT has led to the emergence of legal unification of guarantees or land rights that apply in all regions of Indonesia then, everything regarding the guarantee of land rights uses the same legal basis, namely UUHT.

The Deed of Mortgage Right is an accessor/follow-up agreement; the first agreement is a debt agreement or other agreement that creates a debt relationship. The agreement has characteristics that cannot be separated, arises, and loses depending 
on the first agreement, and if the initial agreement is transferred, then the accessor also switches. The essence of the agreement must be fulfilled; there must be an element of debt that causes the arising of receivable accounts receivable. It is this receivable that requires payment/repayment guarantees (Mustofa, 2014).

Article 1 paragraph (1) UUHT states that mortgage rights are collateral rights charged to land rights as referred to in the Basic Regulation on Agrarian Principles, with or without the other objects which constitute a unit with that land, for repayment of certain debts, which gives a position that is preferred to certain creditors against other creditors.

The definition implies that mortgage is identical to guarantees (Salim H.S., 2011). It means when it charged to ownership rights, the rights of land for buildings and or land for businesses give the primary position to certain creditors who will shift other creditors if the debtor does not keep the promise or commit the breach of contract in the payment of the debt. In other words, it can be said that the first holder of the mortgage right is more preferred to other creditors (Muljadi \& Widjaja, 2006).

The term guarantee is a translation from the Dutch, namely zekerheid or cautie. Zekerheid or cautie generally covers the ways creditors guarantee the fulfillment of their bills, in addition to the general debtor's liability for their goods. Besides the term guarantee, it is also known in Indonesia as agunan. The term of agunan can be read in Article 1 No 23 of Law Number 10 of 1998 on Amendments of Law No 7 of 1992 on Banking.

Agunan is an "additional guarantee which is submitted by the debtor to the banks in order to obtain credit facilities or financing based on shariah principles." Agunan or collateral in this construction is an additional guarantee (accessor). The purpose of collateral is to get facilities from the bank. This guarantee is submitted by the debtor to the bank. The elements of collateral are (Salim H.S., 2011): 1) additional guarantee; 2) submitted by the debtor to the bank; and 3) it aims for obtaining credit or financing facilities.

M. Bahsan argued that guarantee is "everything that a creditor receives and is handed over by a debtor to guarantee debt in the community (Bahsan, 2002)." The term guarantee used because it has been commonly used in the field of Law, in this case relating to the pronouncing of legal guarantees, guarantee institutions, material guarantees, personal guarantees, guarantee rights, and others. Also, it is because the term has been used in several laws and regulations concerning guarantee institutions, as stated in the Mortgage Rights and Fiduciary Laws.

Debt is an obligation that is stated or cannot be stated in the amount of money both directly, or that will arise later, which occurs because of an agreement or law and must be fulfilled by the debtor and if it is not fulfilled by the debtor then, the creditor has the right to get the debtor's assets. Meanwhile, receivables are creditors' claims to 


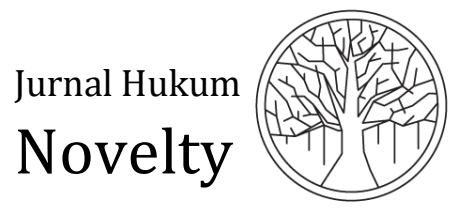

Volume 10, Issue 01, 2019, pp. 43-51

debtors for money, goods or services that are determined and if the debtor is unable to fulfill, the creditor has the right to obtain fulfillment from the debtor's assets. Based on the understanding of the debt agreement, the debt is a specific agreement made between the creditor as the debt lender and the debtor as the recipient of the debt loan. The object is in the form of money, by including the period and obliging the debtor to return the debt accompanied with interest within a specified/agreed period. From this understanding, it can be seen that after the agreement between the debtor and creditor is issued, the principle of pacta sunt servanda (an agreement is legally binding the parties) is applied. Thus, after an agreement is made and the debt agreement has been signed, both parties are bound by the agreement. Therefore, the parties must obey the rules and have good faith in implementing the agreement. In practice, the mortgage right can be implemented in the murābahah financing by using another agreement, i.e., the debt recognition agreement that issued based on the deal between the customer and the bank. This agreement can be used as a basis in applying for a mortgage right in the murābahah contract in the field; this is because the financing contract is not a debt, and the parties may not change the contract.

\section{Conclusion}

In practice, to get regulations which can carry out a mortgage right over murābaḥah financing and can guarantee as well as protect both parties, an additional murābahah financing contract is made based on the agreement of the parties. Also, the contract of acknowledgment of debt was made to acknowledge that the customer had been indebted to the bank so that the banking party was guaranteed for the customer's debt, which is an integral part of the financing agreement. Thus, the object pledged in the debt statement is bound to mortgage rights, so that banks get guarantees for their finance and have prioritized rights over objects when facing the liabilities. Thus, customers can use and enjoy the money they received through murābahah financing contract. By this fact, the parties have been able to make an agreement that can guarantee and protect both parties, as a form of the new agreement made by customers and Shariah banking to fulfill their needs.

\section{References}

Abdullah, R. (2017). Peranan Pembiyaan Murabahah dalam Pengembangan Usaha Pada PT Bank Muamalat. Al-Urban: Jurnal Ekonomi Syariah Dan Filantropi Islam, 1(1), 52.

Afif, Z. N., \& Mawardi, I. (2014). Pengaruh Pembiayaan Murabahah Terhadap Laba Melalui Variabel Intervening Pembiayaan Bermasalah Bank Umum Syariah di Indonesia Periode 2009-2013. Jestt, 1(8), 565-580.

Afrida, Y. (2016). Analisis Pembiayaan Murabahah Di Perbankan Syariah. Jebi (Jurnal Ekonomi Dan Bisnis Islam), 1(2), 155-166.

Agza, Y., \& Darwanto, D. (2017). Pengaruh Pembiayaan Murabahah, Musyarakah, dan Biaya Transaksi Terhadap Profitabilitas Bank Pembiayaan Rakyat Syariah. Iqtishadia: Jurnal Kajian Ekonomi Dan Bisnis Islam, 10(1), 228-248.

Anshori, A. G. (2008). Kapita Selekta perbankan Syariah di Indonesia. Yogyakarta: UII 
Press.

Asiyah, B. N. (2014). Manajemen Pembiayaan Bank Syariah. Yogyakarta: Teras.

Bahsan, M. (2002). Penilaian Jaminan Kredit Perbankan Indonesia. Jakarta: Rejeki Agung.

Haryoso, L. (2017). Penerapan Prinsip Pembiayaan Syariah (Murabahah) Pada Bmt Bina Usaha Di Kabupaten Semarang. Law and Justice, 2(1), 79.

Marzuki, P. M. (2005). Penelitian Hukum. Jakarta: Kencana.

Muhammad, A. (2010). Hukum Perdata Indonesia. Bandung: Citra Aditya Bhakti.

Muljadi, K., \& Widjaja, G. (2006). Hak Tanggungan. Jakarta: Prenada Media Group.

Mustofa. (2014). Tuntunan Pembuatan Akta-Akta PPAT. Yogyakarta: Karya Media.

Otoritas Jasa Keuangan. (2016). Standar Produk Perbankan Syariah Murabahah (S. B. Utomo, Ed.). Retrieved from https://www.ojk.go.id/id/kanal/syariah/beritadan-kegiatan/publikasi/Documents/Pages/Buku-Standar-Produk-PerbankanSyariah-Murabahah/Buku Standar Produk Murabahah.pdf

Poerwadarminto. (2003). Kamus Besar Bahasa Indonesia. Jakarta: Balai Pustaka.

Rachmawati, W., Karim, A., \& Manan, A. (2019). Optimalisasi Pembiayaan Murbahah Berprinsip Bagi Hasil pada Bank Syariah di Indonesia 2010-2015. Jurnal Dinamika Sosial Budaya, 20(2).

Rohman, A. (2017). Pengaruh Kualitas Pelayanan dalam Pembiayaan Murabahah Terhadap Kepuasan Nasabah. IQTISHODIA, Jurnal Ekonomi Syariah, 2(1), 27-37.

Saeed, A. (2004). Menyoyal Bank Syariah: Kritik atas Interpretasi Bunga Bank Kaum Neo-Revivalis. Jakarta: Paramadina.

Salim H.S. (2011). Perkembangan Hukum Jaminan di Indonesia. Jakarta: Raja Grafindo Persada.

Sam, I. (2006). Himpunan Fatwa Dewan Syariah Nasional. Jakarta: Gaung Persada.

Santoso, R., \& Ningrum, I. D. S. (2017). PROFITABILITAS (Suatu Kasus pada PT Bank Syariah Mandiri Periode 2013-2015). Prosiding Sentrinov, 3, 218-229.

Sari, D. W., \& Anshori, M. Y. (2018). Pengaruh Pembiyaan Murabahah, Istishna', Mudhrabah, dan Musyarakah Terhadap Profitabilitas (Studi pada Bank Syariah di Indonesia Periode Maret 2015- Agustus 2016). Accounting and Management Journal, 1(1).

Subekti, R. (2002). Hukum Perjanjian. Jakarta: Intermasa.

Subekti, R., \& Tjitrosudibyo, R. (1992). Kitab Undang-Undang Hukum Perdata. Jakarta: Pradnya Paramita.

Suhendi, H. (2014). Fiqh Muamalah. Jakarta: Rajawali Press.

Supramono, G. (2013). Perjanjian Utang Piutang. Jakarta: Kencana Prenada Media Group. 